\title{
FATTY ACIDS ANALYSIS AND ANTIOXIDANT ACTIVITY OF A LIPID EXTRACT OBTAINED FROM MERCURIALIS ANNUA L. GROWN WILDLY IN JORDAN
}

\author{
NEDHAL AL-DOURI* and ASHOK K. SHAKYA \\ Faculty of Pharmacy and Medical Sciences, Al-Ahliyya Amman University, \\ PO Box 263, Amman-19328, Jordan
}

\begin{abstract}
Aerial parts of Mercurialis annua L. were used in the present study, and fatty acid content in lipid extract was determined using GC-FID. The major fatty acids identified were $\alpha$-linolenic acid (20.3\%), heptadecanoic acid (12.8\%), palmitic acid (11.9\%), pentadecanoic acid (11.7\%), cis-10-pentadecanoic acid (11.2\%), linoleic acid (7.7\%), tridecanoic Acid (4.6\%), stearic (4.4\%), cis-11,14-eicosadienoic acid (3.8\%), beside of minor fatty acids (palmitoleic acid, cis-13,16-docosadienoic acid, arachidic acid, behenic acid, cis-10heptadecenoic acid and myristic acid). Antioxidant properties of the extract were determined via DPPH radical scavenging, $\beta$-carotene bleaching assay and NO radical scavenging assay. The extract produced significant antioxidant activity in-vitro. The data shown here may broaden our knowledge on composition and antioxidant activity of lipid constituents from Mercurialis annua $\mathrm{L}$.
\end{abstract}

Keywords: Mercurialis annua L., hexane extract, antioxidant, GC-FID, Fatty acid methyl ester (FAME), DPPH radical scavenging activity, $\beta$-carotene bleaching assay, NO radical scavenging activity, FT-IR spectrum

Mercurialis genus belongs to the Acalyphoideae subfamily, which consists of 457 plant species. This subfamily is within the Euphorbiaceae family which comprises of 300 genera and 7500 species $(1,2)$. Mercurialis annua L. (M. апnиa L.) is flowering plant species known as annual mercury. It is native to the Middle East, Europe, and North Africa. It is an annual herb growing $10-70 \mathrm{~cm}$ tall. The aerial parts are commonly used for medicinal purposes as laxative, purgative, emetic, emollient. It is recommended to use the extract of aerial parts for the treatment of warts, sores, ear, and eye problems, as well as gynecological diseases such as menstrual molimina (3-5). A homeopathy remedy is made from the plant which is used in the treatment of rheumatism, dropsy, gall bladder, and liver disorders. M. апnua L. has been used in folk medicine as a diuretic and anti-syphilitic. These species have been recommended for relief of anxiety in Moroccan folk medicine. Research indicates that the aqueous extract of the aerial parts has an anxiolytic effect $(6,7)$. Local herbalists in Jordan have used the aqueous extract of aerial parts of $M$. апnиa $L$. for the treatment of hematopoietic malignancies.
The pharmacological effects of methanolic extracts of $M$. апnи $\mathrm{L}$. leaves were studied in our laboratories and showed potent cytotoxic effect on the colorectal adenocarcinoma cell lines HRT-18 and the breast cancer T47D cell lines (8). The methanolic extract did not produce an appreciable inhibitory effect on the growth of Caco-2, MCF-7, A375-S, and WM 136-1A cell lines. There was also no evidence of stimulation of tumor growth on BJAB Burkett's lymphoma and U266 multiple myeloma cell lines by the extract of this plant. It did not exhibit any antimicrobial activity (9). Different flavonoids have been previously reported from the ethanol extract of the aerial parts of this plant (10). Lorenz et al. reported that the chemotaxonomic differences between the $M$. аnnua L. and $M$. perennis L. M. апnиa L. solely contains phaselic acid, whereas M. perennis L. contains a mixture of mercurialis acid and phaselic acid $(4,5)$. An exclusive presence of pyridine-3-carbonitrile and nicotinamide were also reported in the aerial parts of M. annua L. (5). The fixed oils belong to a class of lipids constituted by saturated and unsaturated fatty acids. This class has emollient properties when incorporated in dermatological formulations and researchers of biological activity

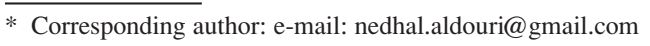


reveal insecticidal potential and larvicidal for these compounds (11). Lipophilic constituents such as hermidin, hermidin quinone, hermidin dimer, along with benzyl alcohol, 2-phenylethanol, 4-methoxy- and 3,4imethoxyphenol, trans-myrtanol, cis-myrtanal and squalene, were reported in M. perennis L. root (12). whereas the aerial parts contained phytol derivative, sterols, tocopherols, lutein, carotenes, pheophytins, triglycerides constituted by linolenic acid, oleic acid, stearic and palmitic acid (4-5). The purpose of this study is to investigate the phytochemical constituents present in the fixed oil from the aerial parts of $M$. annua L. that are growing wildly in Jordan and to evaluate the antioxidant activity of the hexane extract of this plant using different methods.

\section{EXPERIMENTAL}

\section{Material and methods}

\section{Plant material}

Plants were collected from different localities in Jordan and identified by Prof. D. Al-Eisawi, plant taxonomist, Department of Biological Sciences, University of Jordan. A herbarium specimen (Pharm-2017-03) was deposited at the Department of Pharmacy, Al-Ahliyya Amman University, Amman, Jordan.

\section{Extraction}

The dried powdered aerial parts of the plant $(20 \mathrm{~g})$ were extracted with $n$-hexane $(150 \mathrm{~mL})$ three times by maceration for 24 hours. The extracted solution was concentrated under vacuum in a rotatory evaporator at $40^{\mathrm{OP}} \mathrm{C}$, producing $0.96 \mathrm{~g}$ sample.

\section{Infra- red spectroscopy}

The infra-red spectrum of the oily liquid separated from hexane extract (as thin film on $\mathrm{KBr}$ disc) was recorded on Shimadzu IRPrestige-21 spectrophotometer (Shimadzu Co., Japan).

\section{Fatty acid methyl esters (FAMEs)}

FAMEs were synthesized by methylation using sodium methoxide in the presence of methanol at $40^{\circ} \mathrm{C}$. In an Iodine flask, $0.1 \mathrm{~g}$ of hexane extract of aerial part of $M$. апnиa L. was transferred and dissolved in $25 \mathrm{~mL}$ of methanol with the aid of sonication. Sodium methoxide solution $(30 \% \mathrm{w} / \mathrm{v}$ in methanol, $0.1 \mathrm{~g}$ ) was added to it with constant stirring. The reaction mixture was maintained at $40^{\circ} \mathrm{C}$ for $45 \mathrm{~min}$. with constant shaking. Twenty-five milliliters of $n$-hexane were added, and the solution was shaken for $20 \mathrm{~min}$. The reaction was terminated using saturated solution of oxalic acid. The precipitated sodium oxalate was removed after centrifuging the mixture at $5000 \mathrm{rpm}$ for $15 \mathrm{~min}$. The supernatant was collected and dried over anhydrous sodium sulfate and was analyzed by GC-FID (13).

\section{Determination of FAME by GC-FID}

GC analysis of FAME was performed on a Gas Chromatograph (Model Shimadzu 2010, Shimadzu Co. Japan) equipped with a Teknokroma TRBWAX-Omega capillary column $(60 \mathrm{~m} \times 0.25 \mathrm{~mm}$, film thickness $0.25 \mu \mathrm{m}$, Spain; Serial No. NF-31995, (14). The injector temperature was maintained at $240^{\circ} \mathrm{C}$. Operating conditions were as follows: carrier gas-helium, linear velocity $35 \mathrm{~mL} / \mathrm{min}$, injection volume-1 $\mu \mathrm{L}$ and split ratio-1 : 25 . Oven temperature was maintained at $70^{\circ} \mathrm{C}$ for $2 \mathrm{~min}$., then the temperature was raised from 70 to $200^{\circ} \mathrm{C}$ at a rate of $4^{\circ} \mathrm{C} / \mathrm{min}$, followed by $15 \mathrm{~min}$ hold at $200^{\circ} \mathrm{C}$. FAME was identified by comparing their GC retention time with those of 37 pure component FAME mix (Sigma Aldrich Inc., St. Louis, California, USA), methyl ester of $\mathrm{C}_{4}-\mathrm{C}_{24}$ saturated and unsaturated fatty acids. The samples were quantitatively determined through the normalization method without using correction factors: the relative peak area for individual constituents was averaged on three different chromatograms of three independent reactions. The fatty acid composition in the oil was expressed as the percentage of the total fatty acids.

\section{Antioxidant activity}

\section{DPPH scavenging activity}

The extract from M. annua L. was analyzed for its free radical scavenging activity using DPPH according to the reported method with slight modification (15). To perform the analysis, the solution of DPPH $(0.008 \mathrm{~g} \%)$ was prepared freshly in normal hexane. Different concentrations of the extract ( 1.95 to $1000 \mu \mathrm{g} / \mathrm{mL}$ ) in hexane were prepared.

The DPPH solution (1 $\mathrm{mL})$ and samples $(1 \mathrm{~mL})$ were mixed separately and vortexed for $45 \mathrm{~s}$, and kept in the dark at $25 \pm 2^{\circ} \mathrm{C}$ for around $25 \mathrm{~min}$. The absorbance of the solutions was measured at $517 \mathrm{~nm}$ using hexane as blank. DPPH radical scavenging activity was determined and the $\mathrm{IC}_{50}$ was calculated.

DPPH Scavenging activity $=\left|1-\frac{A b s_{\text {control }}}{A b s_{\text {sasmple }}}\right| \times 100$

\section{$\beta$-Carotene bleaching (BCB) Assay}

$\beta$-Carotene $(5 \mathrm{mg}$ ) was dissolved in $50 \mathrm{~mL}$ of chloroform. In a separate Erlenmeyer flask linoleic 
acid (40 mg) and Tween-40 (400 mg) were taken and an aliquot of $\beta$-carotene $(3 \mathrm{~mL})$ solution was added. They were mixed and set aside for $2 \mathrm{~min}$. The chloroform was evaporated using $\mathrm{N}_{2}$ gas. The resultant mixture was dissolved in $100 \mathrm{~mL}$ of distilled water. Immediately after preparation, the absorbance of this solution was recorded at 470 and $700 \mathrm{~nm}$. Different solutions of oil $(50 \mu \mathrm{g} / \mathrm{mL}$ to 1000 $\mu \mathrm{g} / \mathrm{mL}$ ) were prepared in methanol (with the aid of $0.05 \%$ Tween-40). $\beta$-Carotene-linoleic acid emulsion $(1 \mathrm{~mL})$ was mixed with different solutions of oil $(0.25 \mathrm{~mL})$. All the solutions (control and test) were capped and incubated (at $50^{\circ} \mathrm{C}$ ) for 1 hour. The control sample contains an equivalent amount of methanol $(0.05 \%$ Tween- 40$)$. The absorbance of the solutions $\left(\lambda_{470}\right.$ and $\left.\lambda_{700} \mathrm{~nm}\right)$ was determined after 60 min. All determination was carried out in triplicate; the degradation rate (DR) and antioxidant activity were calculated (16).

Degradation rate $(\mathrm{DR})$ of $\beta$-carotene $=$

$$
\operatorname{Ln}\left(\mathrm{A}_{\text {initial }} / \mathrm{A}_{\text {sample }}\right) / 60
$$

Antioxidant activity $(\%)=\frac{(\text { degradfation rate of control }-(\text { degradfation rate of samle })}{\text { degradfation rate of control }} \times 100$

\section{Nitric oxide radical scavenging activity}

The aqueous sodium nitroprusside (SNP) solution reacts with oxygen and generates nitrite ions, these ions can be quantitated by Modified Griess reagent (17). In brief, the reaction mixture contained $10 \mathrm{mM}$ SNP $(0.25 \mathrm{~mL})$, phosphate buffered saline $(\mathrm{pH} 7.4,0.40 \mathrm{~mL})$ and various concentrations of the test solution $(0.10 \mathrm{~mL})$ in test tubes, after incubation at $25^{\circ} \mathrm{C}(150 \mathrm{~min}$.), $0.25 \mathrm{~mL}$ of Griess reagent $(1 \times$, Sigma-Aldrich, USA) was added. The color generated during diazotization of nitrite ions was measured spectrophotometrically at $546 \mathrm{~nm}$. Quercetin (2.5-175 $\mu \mathrm{g} / \mathrm{mL})$ was used as a standard compound for comparison.

\section{Statistical analysis}

Results are expressed as mean \pm standard deviation (SD). Graph-Pad Prism 5 (San Diego, CA, USA) for Windows was used for statistical analyses of experimental data.

\section{RESULTS AND DISCUSSION}

In the present study, the oil content of the aerial parts of $M$. апnиa L. was separated by cold extraction with $\mathrm{n}$-hexane as a solvent and determined to be $4.8 \%$. The FT-IR spectrum (as thin film on $\mathrm{KBr}$ ) reveals characteristic signal at 721 (cis $-\mathrm{CH}=\mathrm{CH}-$ out of plane bending); 837 ( $=\mathrm{CH}_{2}$ out of plane bending); 1170.8 (-CO- stretch), 1201.7 (O- $\mathrm{CH}_{2}$ stretch), 1331, 1377 ( $-\mathrm{CH}_{3}$ bending), 1456 ( $-\mathrm{CH}_{2}$ bending), 1715,1732 ( $\mathrm{C}=\mathrm{O}$ esters); 2853 and $2924 \mathrm{~cm}^{-1}$ (symmetrical and asymmetrical stretching of- $\mathrm{CH}_{2}$ ) and $3001 \mathrm{~cm}^{-1}$ (trans $=\mathrm{C}-\mathrm{H}$ stretch, merged with asymmetrical stretching of- $\mathrm{CH}_{2}$ ) and 3445 (bound $\mathrm{OH}$ stretching) were observed in IR spectrum (Fig. 1). Presence of a weak signal at $1680 \mathrm{~cm}^{-1}$ indicates the presence of non-conjugated fatty acid(18-20).

The fatty acid composition is recorded in Table 1 and structures of various fatty acids identified are

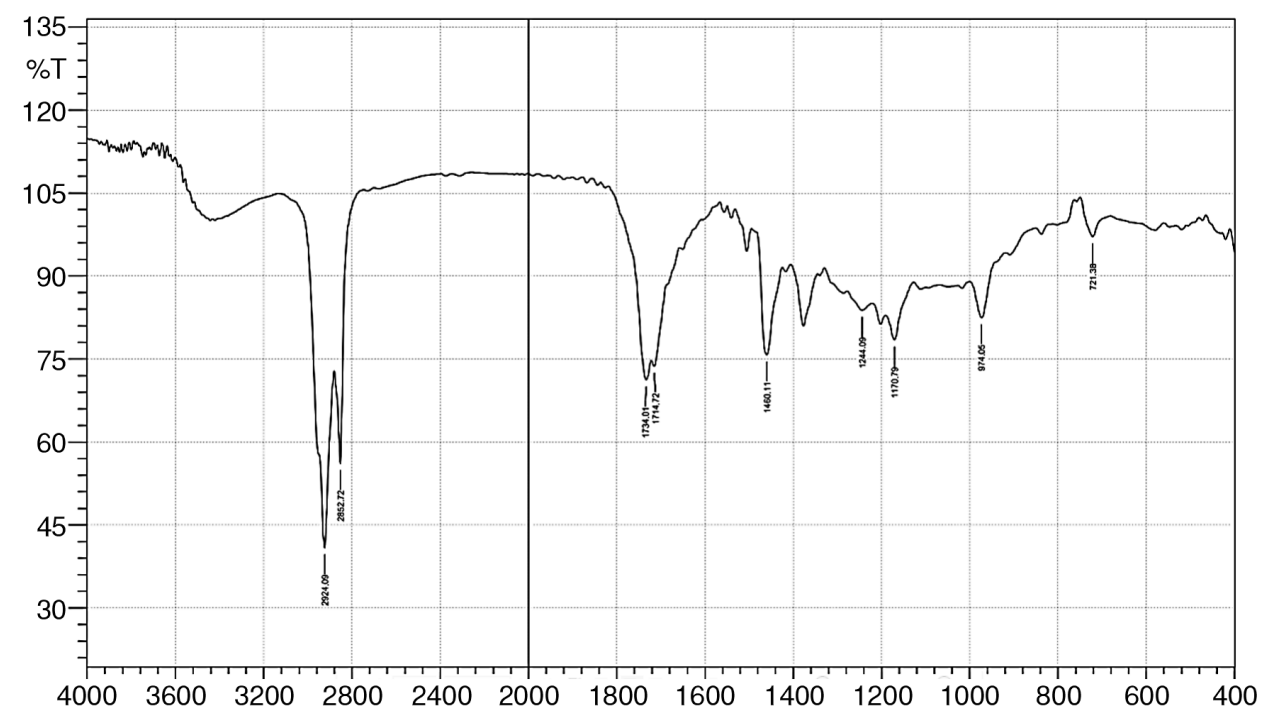

Figure 1. FT-IR spectrum of lipid extract (as a thin film) from aerial parts of M. annua L. 
depicted in Figure 2. The analysis was carried out using capillary GC-FID, and results are presented as percentage content (Table 1, Fig. 3). Saturated fatty acids (SFA) constitute $50.59 \%$ of total fatty acid, which contains heptadecanoic acid (12.78\%), palmitic acid (11.90\%), pentadecanoic acid $(11.75 \%)$, tridecanoic acid $(4.64 \%)$ and stearic acid $(4.37 \%)$ as the main fatty acids. The monounsaturated fatty acids (MUFA) were cis-10-pentadecenoic acid $(11.22 \%)$, palmitoleic acid $(2.81 \%)$ and cis-10heptadecenoic acid $(1.38 \%)$.

The main polyunsaturated fatty acids identified in oil are $\alpha$-linolenic acid (20.29\%), linoleic acid (7.69\%), cis-11,14-eicosadienoic acid $(3.80 \%)$ and cis-13,16-docosadienoic acid $(2.23 \%)$. To the best of our knowledge this research, reports for the first time the fatty acid constituents of the aerial parts of M. annua L. Mizushina et al. (21) have reported the inhibitory effect of various fatty acids including stearic, linoleic acid, $\alpha$-linolenic acid, and Cis11,14-eicosadienoic acid on DNA polymerase $\beta$, which is responsible for controlling diseases. The $\alpha$ linolenic acid $\left[\mathrm{C} 18: 3 \Delta^{9-12-15} \mathrm{cis}\right]$ has antibacterial activity against $H$. pylori, when present as high proportion in oils or fat (22). Linoleic acid [C18:2 $\Delta^{9-12}$ cis] showed topical anti-inflammatory activity in the TPA-induced mice ear edema assay (23). Among other compounds identified were palmitic and stearic acids, both have an anti-inflammatory effect. The results indicate that the aerial parts of M. аnnua $\mathrm{L}$, have different fatty acid composition than the $M$. perennis L. (4).
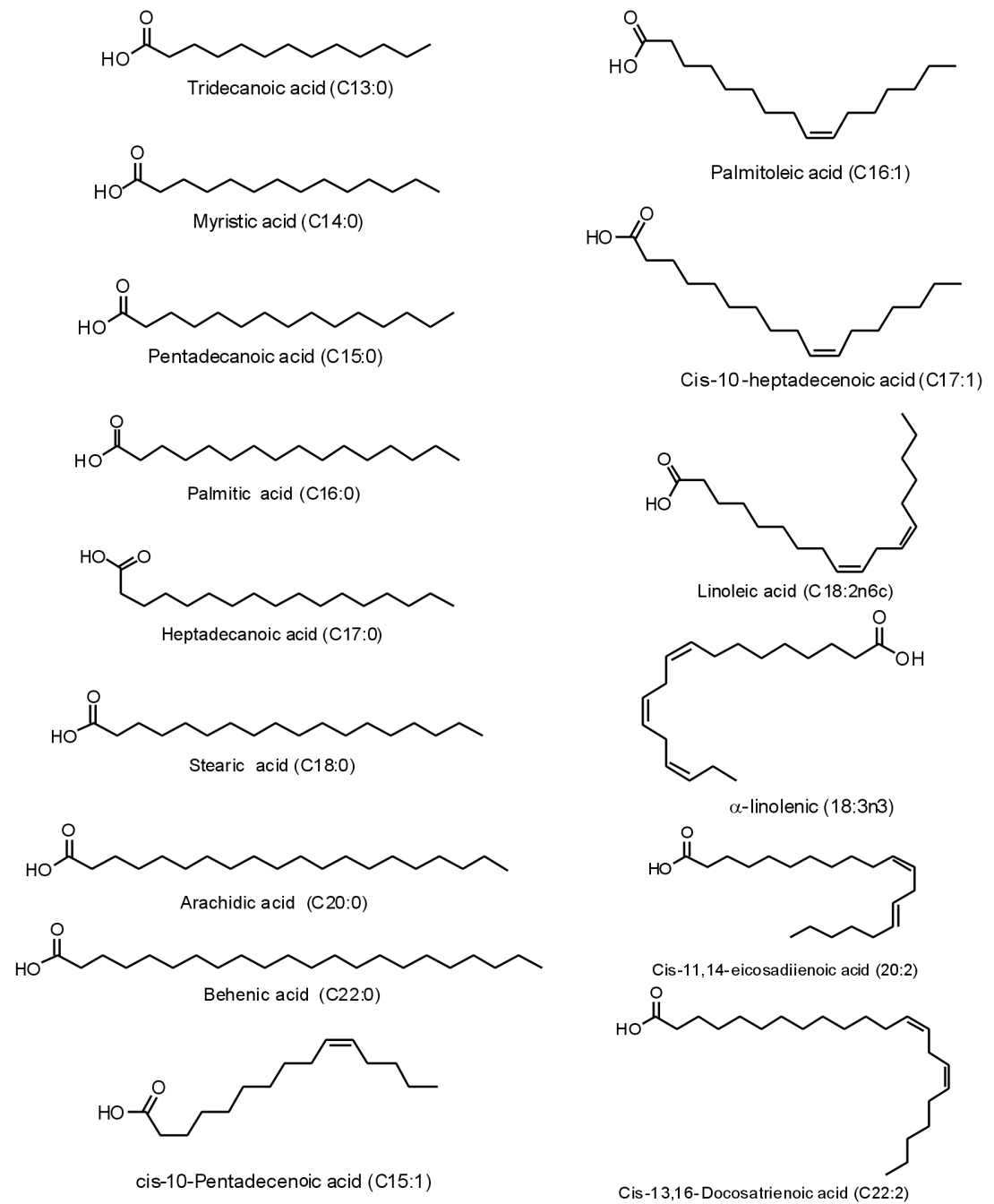

cis-10-Pentadecenoic acid (C15:1)

Cis-1 3,16-Docosatrienoic acid (C22:2)

Figure 2. Chemical structures of fatty acids identified as FAME in a sample 
Table 1. Fatty acid composition (as a percent of Total Fatty Acids) of lipid extract of M. annua L. aerial parts.

\begin{tabular}{|c|c|}
\hline Fatty acid" ${ }^{\#}$ & $\%$ Content* \\
\hline Tridecanoic acid [C13:0] & 4.64 \\
\hline Myristic acid [C14:0] & 1.34 \\
\hline Pentadecanoic acid [C15:0] & 11.75 \\
\hline Palmitic acid [C16:0] & 11.90 \\
\hline Heptadecanoic acid [C17:0] & 12.78 \\
\hline Stearic acid [C18:0] & 4.37 \\
\hline Arachidic acid [C20:0] & 2.11 \\
\hline Behenic acid [C22:0] & 1.70 \\
\hline$\Sigma \mathrm{SFA}^{\mathrm{a}}$ & 50.59 \\
\hline Cis-10-pentadecenoic acid $\left[\mathrm{C} 15: 1 \Delta^{10} \mathrm{cis}\right]$ & 11.22 \\
\hline Palmitoleic acid $\left(\mathrm{C} 16: 1 \Delta^{9} \mathrm{cis}\right)$ & 2.81 \\
\hline Cis-10-heptadecenoic acid $\left(\mathrm{C} 17: 1 \Delta^{10} \mathrm{cis}\right)$ & 1.38 \\
\hline$\Sigma$ MUFA $^{\mathrm{b}}$ & 15.41 \\
\hline Linoleic acid $\left[\mathrm{C} 18: 2 \Delta^{9-12} \mathrm{cis}\right]$ & 7.68 \\
\hline$\alpha$-linolenic acid $\left[\mathrm{C} 18: 3 \Delta^{9-12-15} \mathrm{cis}\right]$ & 20.29 \\
\hline Cis-11,14-eicosadienoic acid [C20:2 $\left.\Delta^{11-14} c i s\right]$ & 3.80 \\
\hline Cis-13,16-docosadienoic acid [C22:2 $\left.\Delta^{13-16} \mathrm{cis}\right]$ & 2.23 \\
\hline$\Sigma \mathrm{PUFA}^{\mathrm{c}}$ & 34.00 \\
\hline
\end{tabular}

"Fatty Acids were analyzed as fatty acid methyl esters (FAME); *Mean of three replicates; ${ }^{\text {aSFA }}=$ Saturated fatty acids; ${ }^{\mathrm{D}} \mathrm{MUFA}=$ monounsaturated fatty acids; ${ }^{\mathrm{P} U F A}=$ Polyunsaturated fatty acids

Table 2. Antioxidant activity of the lipid extract from M. annua L. aerial parts.

\begin{tabular}{|c|c|c|c|}
\hline \multicolumn{4}{|c|}{$\mathrm{IC}_{50}(\mu \mathrm{g} / \mathrm{mL})$} \\
\hline Sample & $\begin{array}{c}\text { DPPH radical } \\
\text { scavenging activity* }\end{array}$ & $\begin{array}{c}\beta \text {-Carotene bleaching } \\
\text { Assay* }\end{array}$ & $\begin{array}{c}\text { NO radical scavenging } \\
\text { activity* }\end{array}$ \\
\hline Oil & $170.5 \pm 2.1$ & $265.5 \pm 2.8$ & $385.0 \pm 4.8$ \\
\hline Rutin & - & $8.2 \pm 0.5$ & \\
\hline$\alpha$-Tocopherol & $85.6 \pm 1.8$ & - & - \\
\hline Quercetin & - & - & $51.4 \pm 1.8$ \\
\hline
\end{tabular}

$*$ Values are given as Mean $\pm \operatorname{SD}(\mathrm{n}=3)$

The presence of these constituents in the fixed oil is important phytochemically and therefore its biological activities were evaluated. DPPH scavenging activity $\left(\mathrm{IC}_{50}\right)$ was calculated (Table 2 ), the lipid extract at concentrations ranging between 1.95 to $1000 \mu \mathrm{g} / \mathrm{mL}$ showed comparable antioxidant activity. The $\mathrm{IC}_{50}$ of oil against $\mathrm{DPPH}$ radical was $170.5 \pm 2.1 \mu \mathrm{g} / \mathrm{mL}$, which was comparable to the $\mathrm{IC}_{50}$ value of $\alpha$-tocopherol $(85.6 \pm 1.8 \mu \mathrm{g} / \mathrm{mL})$. The antioxidant activity could be attributed due to the presence of unsaturated fatty acids and other com- pounds. The $\mathrm{IC}_{50}$ value in case of $\beta$-carotene bleaching assay was $265.5 \pm 2.8 \mu \mathrm{g} / \mathrm{mL}$, compared to $8.2 \pm 0.5 \mu \mathrm{g} / \mathrm{mL}$ of rutin. As far as nitric oxide scavenging activity of extract is concerned, the sample produced a weak activity with $\mathrm{IC}_{50}$ value of $385.0 \pm 4.8 \mu \mathrm{g} / \mathrm{mL}$, compared to that of quercetin with $\mathrm{IC}_{50}$ value of $51.4 \pm 1.8 \mu \mathrm{g} / \mathrm{mL}$. These findings indicate that the extract has significant antioxidant activity which might be responsible for the other biological activities and protecting the oxidation of plant constituents. 


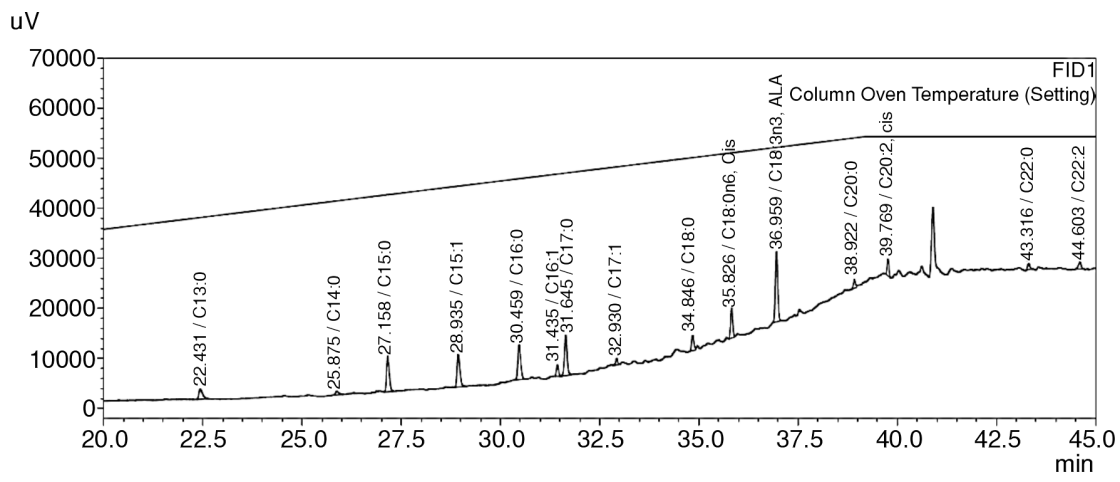

Figure 3. GC-FID analysis of fatty acid methyl esters from a lipid extract of $M$. annua L. aerial parts

\section{CONCLUSION}

This study describes the fatty acid composition and quantification of lipid extract of aerial parts of M. annua L. growing in Jordan for the first-time using GC-FID. The results indicate the presence of the $\alpha$-linolenic acid as main polyunsaturated fatty acids along with linoleic acid, and saturated fatty acids like heptadecanoic acid, palmitic, pentadecanoic, tridecanoic and stearic acid. Cis-pentadecenoic acid along with small amount of palmitoleic and cis-10-heptadecenoic acid were identified as MUFA. The other fatty acids were arachidic acid, behenic acid, myristic acid, and cis-13,16-docosadienoic acid. The FT-IR, DPPH scavenging activity, $\beta$-carotene bleaching assay and NO radical scavenging activity were recorded also.

\section{Acknowledgments}

The authors would like to thank, Dean of Faculty of Pharmacy and Medical Sciences, Higher Education and Scientific Research, Al-Ahliyya Amman University, Amman, Jordan for their support during the research work. Authors wish to thank Dr. Fayrouz Abousweilem, Department of Business for proof reading and editing of the manuscript.

\section{REFERENCES}

1. Frohne D., Jensen U.: Systematik des Pflanzenreichs, $4^{\text {th }}$ edn., p. 220, Gustav Fischer Verlag, Stuttgart, Jena, New York, 1992.

2. Krahenbuhl M., Yuan Y.M., Kupfer P.: Plant Syst. Evol. 234, 155 (2002).
3. Madaus G.: Lehrbuch der biologischen Heilmittel, 2nd edn. p. 1938, Nachdruck der Ausgabe Leipzig. Medimed Verlag, Hildesheim 1979.

4. Lorenz P., Hradecky M., Berger M., Bertrams J., Meyer U., Stintzing F.C.: Phytochem. Anal. 21, 234 (2010).

5. Lorenz P., Duckstein S., Conrad J., Knödler M., Meyer U., Stintzing, F.C.: Chem. Biodivers. 9, 282 (2012).

6. Doukkali Z., Kamal R., Jemeli M.E., Nadjmouddine M., Zellou A. et al.: J. Pharma Reports. 1, 104 (2016).

7. Obbard D.J., Harris S.A., Buggs R.J., Pannell J.R.: Evolution 60, 1801 (2006).

8. Bustanji Y., AlDouri N., Issa A., Mashallah S., Assaf A. et al.: Sci. Res. Essays. 7, 3218 (2012).

9. Assaf A.M., Haddadin R.N., Aldouri N.A., Alabbassi R., Mashallah S. et al.: J. Ethnopharmacol. 145, 728 (2013).

10. Aquinoa R., Behara I., D'agostinoa M., De.Simonea F., Schettino O., Pizzaa C.: Biochem. Syst. Ecol. 15, 667 (1987).

11. Ljubuncic P., Azaizeh H., Portnaya I., Cogan U., Said O. et al.: J. Ethnopharmacol. 99, 43 (2005).

12. Ostrozhenkova E., Eylert E., Schramek N., Golan-Goldhirsh A., Bacher A., Eisenreich W.: Phytochem. 68, 2816 (2007).

13. Elagbar Z.A., Naik R.R., Shakya A.K.: Oriental J. Chem. 34, 1368 (2018).

14. Naik R.R.: Oriental J. Chem. 31, 1929 (2015).

15. Elagbar Z.A., Naik R.R., Shakya A.K., Bardaweel S.K.: J. Chem. (Hindawi), 6948098, 2016. http://dx.doi.org/10.1155/2016/6948098.

16. Lim Y.Y., Quah E.P.L.: Food Chem. 103, 734 (2007). 
17. Abuhamdah S., Abuhamdah R., Shakya A.K., Al-Olimat S.M., Chazot P.: Afr. J. Pharm. Pharmacol. 8, 1235 (2014).

18. Guillén M.D., Cabo N.: J. Am. Oil Chem. Soc. 74, 1281 (1997).

19. Lerma-García M.J., Ramis-Ramos G., HerreroMartínez J.M., Simó-Alfonso E.F.: Food Chem. 118, 78 (2010).

20. Ren J., Chung S.H.: J. Agricult. Food Chem. 55, 5073 (2007).
21. Mizushina Y., Yoshida S., Matsukage A., Sakaguchi K.: Biochim. Biophys. Acta 1336, 509 (1997).

22. Thompson L., Cockayne A., Spiller R.C.: Gut. 35, 1557 (1994).

23. Morais S.M., Nascimento J.E.T., Silva A.A.S., Honório Junior J.E.R., Pinheiro D.C.S.N., Oliveira R.V.: Acta. Sci. Vet. 45, 1437 (2017).

Received: 11.04.2018 